\title{
Overweight and Obesity in Preschoolers in a Region in Western Turkey and Related Factors
}

\author{
Celalettin Cevik ${ }^{1}$ Sibel Ergun ${ }^{1}$, Ayse Karadas ${ }^{1}$, Turkan Calıskan ${ }^{1}$, Nuriye Karadag ${ }^{2}$ \\ ${ }^{1}$ Balıkesir Üniversitesi, Sağlık Bilimleri Fakültesi, Hemşirelik Bölümü Balıkesir, Türkiye \\ ${ }^{2}$ Balıkesir Üniversitesi, Sağlık Bilimleri Fakültesi, Ebelik Bölümü Balıkesir, Türkiye \\ email: celalettincevik@balikesir.edu.tr, sibel.ergun@balikesir.edu.tr, aysegulserkaradas@gmail.com, \\ turkanc@balikesir.edu.tr,nkaradag@balikesir.edu.tr, \\ Orcid: 0000-0002-1123-6196 \\ Orcid: 0000-0003-1227-5856 \\ Orcid: 0000-0003-3955-2980 \\ Orcid: 0000-0002-7808-2363 \\ Orcid: 0000-0002-8341-8888 \\ *Sorumlu Yazar / Corresponding Author: Sorumlu Yazar: Celalettin Cevik \\ Gönderim Tarihi / Received: 11.07.2019 \\ Kabul Tarihi / Accepted: 23.12.2019 \\ DOI: $10.34087 /$ cbusbed.590832
}

Amaç: Obezite ve fazla kilolu olma giderek artan önemli bir halk sağlığı sorunudur. Bu çalışmanın amacı okul öncesi çocuklarda fazla kilolu / obez olma sıklığı ve ilişkili faktörlerin saptanmasıdır.

Gereç ve Yöntem:Kesitsel tipteki bu çalışma Balıkesir ilinde Ekim 2015- Ocak 2016 tarihleri arasında yürütülmüştür. Araştırmada 1061 okul öncesi çocuğa çok aşamalı örnekleme yöntemiyle ulaşılmıştır. Veri yüz yüze, sossyodemografik özelikler formu ve antropometrik ölçümler yapılarak toplanmıştır. Verilerin analizisnde, sayı, yüzde, ki kare testi, bivariate ve multivariate regresyon analizi kullanılmıştır.

Bulgular:Katılımcıların \%4.9'u fazla kilolu \%11.2'si obezdir. Obezite/fazla kilolu olma durumu erkek çocuklarda (1.34 [\%95 GA**: 1.02-1.80]), apartmanda yaşayanlarda (1.78 [\%95 GA: 1.54-4.82]), ailesinde obezite öyküsü olanlarda ( 3.02 [\% 95 GA: 1.62-5.66]), öğün atlayanlarda (1.56 [\% 95 GA: 1.05,2.36]), yemek yerken başka şeylerle ilgilenenlerde (1.68 [\% 95 GA: 1.27-2.22]) ve annesi üniversite mezunu olanlarda (1.94 [\% 95 GA: 1.04 3.64]) yüksektir $(\mathrm{p}<0.05)$.

Sonuç:Obezite/fazla kilolu olma sıklığı yüksek bulunmuştur. Sedanter yaşam tarzı ve kötü beslenme düzeyi arttıkça obezite artmaktadir.

Anahtar kelimeler: Obezite, Okul Öncesi Dönem, Risk Faktörleri, Sedanter Yașam

\section{Abstract}

Objective:The increase in the prevalence of overweight and obesity in children is one of the major public health problems nowadays. The aim of the present study was to determine the prevalence of overweight / obesity and related factors in preschool children.

Matherials and Methods:The cross-sectional study was carried out in the city center of Balıkesir from October 2015 to January 2016. The study sample included 1061 children selected using the multistage sampling method. The study data were collected through face-to-face interviews with a structured questionnaire and anthropometric measurements. Numbers, percentages, chi-square test, bivariate and multivariate regression analysis were used in the analysis.

Results:Of the participants, $4.9 \%$ were overweight and $11.2 \%$ were obese. The prevalence of overweight and obesity was higher in boys (AOR*=1.34 [95\% CI**: 1.02-1.80]), those living in an apartment (AOR = 1.78 [95\% CI: $1.54-4.82]$ ), those having an extended family ( $\mathrm{AOR}=2.51$ [95\% CI: $1.03-6.12])$, those with a family history of obesity $(\mathrm{AOR}=3.02[95 \% \mathrm{CI}: 1.62-5.66])$, those who skipped a meal $(\mathrm{AOR}=1.56[95 \% \mathrm{CI}: 1.05,2.36]),=1.68$ [95\% CI: 1.27-2.22]), those interested in other things while eating (AOR $=1.68$ [95\% CI: 1.27-2.22]) and those whose mothers were university graduates $(\mathrm{AOR}=1.94$ [95\% CI: 1.04-3.64]) $(\mathrm{p}<0.05)$.

Conclusions: The prevalence of overweight / obesity in preschool children is high. Sedentary lifestyle and poor diet increase the prevalence of obesity.

Key words: Obesity, Preschool Period, Risk Factors, Sedentary Life. 


\section{Introduction}

The term overweight refers to excess body weight for a particular height whereas the term obesity is used to define excess body fat[1]. Childhood obesity is a forerunner of metabolic syndrome, poor physical health, mental disorders, respiratory problems and glucose intolerance, all of which can track into adulthood[2].

Childhood obesity has increased in both developed and developing countries in the last 30 years, in developed countries being higher[3]. The worldwide prevalence of childhood obesity which is on the increase was $6.7 \%$ in 2010 and is expected to be $9.1 \%$ in 2020 . According to the results of Turkey Nutrition and Health Survey (TNHS, 2010) conducted by the Ministry of Health, of the children under five years of age, $17.9 \%$ were overweight and $8.5 \%$ were obese [4]. According to the nationwide Turkey Demographic and Health Survey (TDHS) 2013, 10.9\% of children under five years of age were obese [5].

Childhood obesity is a complex problem caused by various factors such as environmental issues, family health behavior, physical activity, diet and sedentary lifestyle [6]. Childhood obesity is also affected by the family's income level, educational level and socioeconomic status [7,8]. Although healthy eating and active living habits of children are of importance, children can gain weight as a result of consuming foods high in energy and low in nutrients in daily life, which causes them to develop chronic diseases in the future[9]. High socio-economic development of Balikesir, paves the way for an increase in obesity. Our search for studies carried out to investigate the prevalence of obesity and related factors in preschool children in Balıkesir demonstrated a gap in the literature.

The present study was aimed at determining the prevalence of overweight / obesity and related factors in preschoolers in the city center of Balıkesir

\section{Subject and Methods}

This cross-sectional study was conducted in 19 nursery schools in the city center of Balıkesir between October 2015 and January 2016. The study population comprised 2238 3- to 5-year-old children. The sample size was calculated as 1297 in the Gpower 3.1 program. The power, prevalence, type I error and deviation rates were $95 \%, 10 \%, 5 \%$ and $5 \%$ respectively. The study included 1061 children whose parents filled in and returned the family information forms. While the sample size was determined, the multistage sampling method was used. The sample size was determined in proportion to the size of the study population in 19 nursery schools in the city center of Balikesir. Then, based on the class lists obtained from each school, the systematic sampling method was used to form the sample.

The dependent variable of the study is the children's being overweight / obese. The independent variables are parents' socio-demographic characteristics such as the employment and educational status, and children's life style-related activities such as the way of transportation to school, time spent watching TV and eating behaviors. The study data were collected by the researchers with the family obesity information questionnaire and anthropometric measurements (height and weight).

2.1 Family obesity information questionnaire: The questionnaire developed by the researchers based on the literature includes questions on the family type, household income level and place of residence. It also has questions about parents (their height and weight, whether they do sports, how much time they spend watching TV, whether they have chronic diseases) and children (whether they skip meals, how often they do sports, how much time they spend watching TV, whether they consume fast food, how long their sleep duration is and what their weekly eating habits are).

While the weight of the children was measured with a 100-gr precision SECA brand digital scale, their height was measured with a 1-mm precision SECA brand height-measuring rod. Before weight measurement, the children took off their shoes and upper garments. For height measurement, they removed head accessories such as hairpins, they were asked to keep their shoulders in the upright position with the arms at sides, not to bend the knees, to evenly distribute their weight on both feet. After the weight and height measurements, their body mass index (BMI) was calculated. BMI z-score is recommended as the best measure of adiposity on single occasion measurements ${ }^{[10]}$. The BMI of the study group was evaluated according to the $\mathrm{z}$-score. Body mass index have been calculated, National standards was used to calculate the scores, and classification was done as normal, overweight and obese. The Z-score indicates how many standard deviations are below or above the median value of the reference population[11, 12].

Data analysis was performed using the Statistical Program for Social Sciences for Windows 22.0. In the analysis, percentage, arithmetic mean, standard deviation, chi-square, and Fisher's exact test were used. Effects of social and environmental determinants on overweight / obesity were analysed with odds ratios (ORs) and the backward elimination method in the logistic regression analysis.

Before the study was carried out, permission from the Balıkesir Provincial Directorate of National Education, ethical approval from the Medipol University Ethics Committee (2015/506) and written consent from the families were obtained.

\section{Results}

Of the participants, $66.8 \%$ were 5 years old, $53.6 \%$ were male, $92.3 \%$ were living in the apartment, $95.4 \%$ had a nuclear family, $33.4 \%$ had overweight or obese mothers, and $38.9 \%$ had overweight or obese fathers. While $50.2 \%$ of the mothers were university graduates, $56.4 \%$ 
of the fathers were university graduates. Of the participants, $57.3 \%$ consumed ready to eat food once or twice a week, $51.1 \%$ skipped meals, $74.7 \%$ were interested in other things while eating, $78.3 \%$ did not exercise, $40.4 \%$ watched TV for 2 hours a day, $69.2 \%$ went to school by motor vehicle, $61.5 \%$ ate at fast food restaurants 1-3 times a month, $4.9 \%$ were overweight and $11.2 \%$ were obese (Table 1 ).

Table 1. Sociodemographic characteristics of the children participating in the study




185.865, p: 0.001), those who skipped meals $\left(\chi^{2}\right.$ : $15.600, \mathrm{p}: 0.001)$, those interested in other things while eating $\left(\chi^{2}: 13.061, \mathrm{p}: 0.001\right)$, those going to school by motor vehicle $\left(\chi^{2}: 9.121, \mathrm{p}: 0.003\right)$ and those whose mothers were university graduates $\left(\chi^{2}: 23.828, \mathrm{p}: 0.001\right)$ ( $\mathrm{p}<0.05)$. There was no significant correlation between overweight / obesity and variables such as age, health insurance, breastfeeding status, parents' employment status, father's education status and eating at fast food restaurants $(\mathrm{p}>0.05)$.

Table 2 shows the factors affecting overweight or obesity analyzed with backward elimination method in the logistic regression model. The prevalence of overweight and obesity was higher in boys $\left(\mathrm{AOR}^{*}=\right.$ 1.34 [95\% CI**: 1.02-1.80]), those living in an apartment $(\mathrm{AOR}=1.78$ [95\% CI: 1.54-4.82]), those having an extended family ( $\mathrm{AOR}=2.51$ [95\% CI: 1.03 $6.12]$ ), those with a family history of obesity (AOR = 3.02 [95\% CI: 1.62-5.66]), those who skipped a meal $(\mathrm{AOR}=1.56[95 \% \mathrm{CI}: 1.05,2.36]),=1.68[95 \% \mathrm{CI}:$ 1.27-2.22]), those interested in other things while eating $(\mathrm{AOR}=1.68$ [95\% CI: 1.27-2.22] $)$ and those whose mothers were university graduates $(\mathrm{AOR}=1.94[95 \%$ CI: 1.04-3.64]) ( $\mathrm{p}<0.05)$. (*AOR = adjusted odds ratio, $* * \mathrm{CI}=$ Confidence Interval $)$

Table 2. Factors affecting overweight and obesity according to the logistic regression model

\begin{tabular}{|l|l|l|l|l|}
\hline \multicolumn{2}{|l|}{ Factors } & $\mathbf{p}$ & Crude OR & Adjusted OR \\
\hline Gender & $\begin{array}{c}\text { Girl (ref) } \\
\text { Boy }\end{array}$ & 0.040 & $1.51(1.02-2.27)$ & $1.34(1.02-1.80)$ \\
\hline Type of residence & $\begin{array}{c}\text { Private house (ref) } \\
\text { Apartment }\end{array}$ & 0.004 & $2.35(1.94-3.91)$ & $1.78(1.54-4.82)$ \\
\hline Family type & $\begin{array}{c}\text { Nuclear (ref) } \\
\text { Extended }\end{array}$ & 0.042 & $3.58(1.96-6.52)$ & $2.51(1.03-6.12)$ \\
\hline Family history of obesity & $\begin{array}{c}\text { No (ref) } \\
\text { Yes }\end{array}$ & 0.001 & $4.27(3.32-5.48)$ & $3.02(1.62-5.66)$ \\
\hline Skipping meals & $\begin{array}{c}\text { No (ref) } \\
\text { Yes }\end{array}$ & 0.033 & $1.77(1.32-2.36)$ & $1.56(1.03-2.36)$ \\
\hline $\begin{array}{l}\text { Being interested in other things } \\
\text { while eating }\end{array}$ & $\begin{array}{c}\text { No (ref) } \\
\text { Yes }\end{array}$ & 0.001 & $3.63(2.36-5.57)$ & $1.68(1.27-2.22)$ \\
\hline Mother's education status & $\begin{array}{c}\text { High school or } \\
\text { lower (ref) } \\
\text { University }\end{array}$ & 0.026 & $2.20(1.06-5.44)$ & $1.94(1.04-3.64)$ \\
\hline
\end{tabular}

Nagelkerke $\mathrm{R}^{2}=0.47\left(\chi^{2}: 63.436\right.$ p:0.001)

\section{Discussion}

Since obesity developed in pre-school period tends to continue in later ages and during adulthood, it is important to diagnose and prevent it at an early stage. In the present study, the prevalence of overweight/obesity in the participating children was $16.1 \%$ [overweight $(4.9 \%)$, obese $(11.2 \%)$ ]. The review of similar studies conducted in various countries demonstrated that while the prevalence of overweight / obesity in preschoolers varied between $4 \%$ and $21 \%$ in some studies, which was consistent with the results of the present study ${ }^{[4,5,9,13-}$ ${ }^{17]}$, it was lower in some studies ${ }^{[14-17]}$, and higher in some other studies ${ }^{[18,19]}$. For instance, the rate was higher in two studies conducted in Iran and Vietnam $\left[35.7 \%{ }^{[18]}\right.$ and $21 \%{ }^{[20]}$ respectively], and was lower in a study conducted in Cameroon $\left[8 \%{ }^{[16]}\right]$ than that in the present study. Such a difference may have stemmed from the type of study and the place where the study was conducted. Lack of role models, lack of parks and playgrounds especially in urban areas, concerns about the security of the neighbourhood or the environment and overuse of motor vehicles for transportation restrict physical activities of children ${ }^{[21]}$. Although the prevalence of overweight/obesity in the present study was close to that in Turkey, it was still a bit higher, which is probably due to the fact that it was conducted with children living in a city in the western part of Turkey, where people's socio-economic level is high, which makes people more prone to obesity. Consistent with the literature, the prevalence of overweight or obesity was higher in the boys than that in the girls, which may be due to the fact that the boys were more affected by environmental conditions such as unhealthy feeding behaviour than were the girls ${ }^{[13,15-17,22]}$. The prevalence of overweight/obesity was also high in the children with high family income. Although the income status lost its significance in the further analysis, the high level of education of a woman, an indicator of higher socioeconomic development, was a determinant of obesity in the present study. Of the participating children, those whose mothers were university graduates were more obese / overweight than the other children. Similarly, the prevalence of obesity was higher in children whose mothers were employed or had a high education level ${ }^{[5,18,23,24]}$. This is probably due to the fact that a working mother has limited time to cook when she comes back home from work, and thus she 
prefers carbohydrate-based foods and instant foods because they are easier to prepare. The results of TDHS 2013 revealed that in children under five years of age, the prevalence of obesity increased as the welfare of the family increased, which supports the findings of the present study ${ }^{[5]}$. Similarly, in several other studies, the prevalence of obesity was found to be higher among those whose socio-economic level was high ${ }^{[13,23,25]}$. In the present study, the prevalence of obesity was higher among those living in apartments than among those living in private houses, which may be due to the fact that those living in apartments had better living conditions. That obesity is more common in families with high socioeconomic level in Turkey may be associated with the fact that obesity is not regarded as a health problem in Turkish society. The prevalence of obesity was higher in the children having extended families than that in the children having nuclear families, which may be due to the fact that in Turkish society, extended families generally have a patriarchal family structure and that in these families, children's not being overweight but being underweight is perceived as a problem. In this case, the presence of family history of obesity affects the prevalence of overweight or obesity, which is consistent with the literature ${ }^{[16]}$. Given the effects of genetics and families' eating habits on obesity, this is an expected result. In the study group, the prevalence of overweight / obesity was high in the children who skipped meals, did not have refreshments and/or ate in fast food restaurants 2-3 days a week. Consuming energy-rich foods or not having a regular diet is associated with obesity, which is supported by similar findings in the literature ${ }^{[26,27]}$ In the present study, the prevalence of overweight or obesity was higher in the participants living in an apartment, not exercising or watching television for a long time. This result is similar to those of the studies conducted in $\operatorname{Iraq}^{[24]}$, Iran ${ }^{[18]}$ and Kenya ${ }^{[19]}$. Children's watching television long hours not only prevents them from participating in physical activities adequately but also encourages them to consume sweet and salty foods ${ }^{[14}$, ${ }^{28]}$. One of the interesting results of the present study is that the children whose mothers were university graduates were more obese than were the others. This is probably because the university graduate mothers were working mothers, and thus their children were looked after by a nanny or by a family elder as a result of which the traditional family structure was protected. In fact, in the present study, the prevalence of obesity was high in children living in an extended family.

\section{Conclusions}

In the present study, one out of ten preschoolers were overweight or obese. The prevalence of overweight and obesity was higher in boys, those whose mothers' education level was higher, those with family history of obesity, those who skipped a meal, those living in an apartment, those who watched television for a long time, and those interested in other things such as watching TV or using mobile phones while eating.

\section{Strengths and Limitations of the Study}

The present study is of importance, because it is one of the first studies investigating the prevalence of obesity and related factors in pre-schoolers in the region where it was conducted, and because it provides data to decision makers. Because the present study is not community-based, it can be generalized only to children who receive pre-school education.

\section{Declaration of Conflicting Interests}

The authors declared no potential conflicts of interest with respect to the research, authorship, and/or publication of this article.

\section{Acknowledgments}

The authors would like to extend their sincere thanks to anyone who contributed to this study. The study was supported by Balıkesir University Scientific Research Projects unit (BAP.2015.0001).

\section{References}

1. Health NIo, National Heart L, Institute B. Disease and Conditions Index: what are overweight and obesity. Bethesda, MD: National Institutes of Health. 2010.

2. Cole TJ, Bellizzi MC, Flegal KM, Dietz WH. Establishing a standard definition for child overweight and obesity worldwide: international survey. Bmj. 2000;320(7244):1240.

3. World Health Organization. Global Strategy on Diet, Physical Activity and Health 2012 [13.10.2018]. Available from: http://www.who.int/dietphysicalactivity/strategy-engpdf Accessed in 2019 (Jan 18).

4. Ministry of Health in Turkey. Turkey Nutrition and Health Survey 2010: Nutritional status and habits of evaluation results report. Ankara, Ministry of Health General Directorate of Health Research. 2014.

5. Hacettepe University Institute of Population Studies. Turkey's population and health survey. Hacettepe University Institute of Population Studies, Ministry of Health, Maternal and Child Health and Family Planning General Directorate of the Prime Ministry State Planning Organization and TUBITAK, Ankara, Turkey. 2013;2013.

6. Keane E, Layte R, Harrington J, Kearney PM, Perry IJ. Measured parental weight status and familial socio-economic status correlates with childhood overweight and obesity at age 9. PloS one. 2012;7(8):e43503.

7. Bammann K, Gwozdz W, Lanfer A, Barba G, De Henauw S, Eiben $\mathrm{G}$, et al. Socioeconomic factors and childhood overweight in Europe: Results from the multi-centre IDEFICS study. Pediatric obesity. 2013;8(1):1-12.

8. Dev DA, McBride BA, Fiese BH, Jones BL, Cho obotSKRT, Hyunkeun. Risk factors for overweight/obesity in preschool children: an ecological approach. Childhood obesity. 2013;9(5):399-408.

9. Lobstein T, Jackson-Leach R, Moodie ML, Hall KD, Gortmaker SL, Swinburn BA, et al. Child and adolescent obesity: part of a bigger picture. The Lancet. 2015;385(9986):2510-20.

10. Cole TJ, Faith MS, Pietrobelli A, Heo M. What is the best measure of adiposity change in growing children: BMI, BMI\%, BMI z-score or BMI centile? European journal of clinical nutrition. 2005;59(3):419.

11. Köksal G, Gökmen H. Okul Öncesi Dönemde Obezite. TC Să̆lık Bakanlığı Temel Sağlık Hizmetleri Genel Müdürlüğ̈̈ Beslenme ve Fiziksel Aktiviteler Daire Başkanlı̆̆ı Yayınları, Ankara. 2008.

12. Kerkez Fİ. 4-5 Yaş Çocukların Sağlıklı Besin Bilgisi ve Tercihinin İncelenmesi. E-Uluslararası Eğitim Araştırmaları Dergisi. 2017;9(3):47-59.

13. Önal Sibel, Özdemir A, Meşe C, Koca B. Evaluation of Prevalence of Malnutrition and Obesity in Preschool Children: A Case Study in Ankara. DTCF Journal. 2016;56(1):210-25. 
14. Sorrie MB, Yesuf ME, GebreMichael TG. Overweight/obesity and associated factors among preschool children in Gondar City, Northwest Ethiopia: A cross-sectional study. PloS one. 2017;12(8):e0182511.

15. Gebremedhin S. Prevalence and differentials of overweight and obesity in preschool children in Sub-Saharan Africa. BMJ open. 2015;5(12):e009005.

16. Tchoubi S, Sobngwi-Tambekou J, Noubiap JJN, Asangbeh SL, Nkoum BA, Sobngwi E. Prevalence and risk factors of overweight and obesity among children aged 6-59 months in Cameroon: a multistage, stratified cluster sampling nationwide survey. PloS one. 2015;10(12):e0143215.

17. Hassanzadeh-Rostami Z, Kavosi E, Nasihatkon A. Overweight and obesity among preschool children from Fars province of Iran: prevalence and associated factors. Journal of research in health sciences. 2016;16(1):26-30.

18. Hajian-Tilaki K, Heidari B. Childhood obesity, overweight, socio-demographic and life style determinants among preschool children in Babol, northern Iran. Iranian journal of public health. 2013;42(11):1283

19. Wandia FB, Ettyang G, Mbagaya G. Prevalence of and factors associated with overweight and obesity among nursery schoo children aged 3-6 years in Eldoret Municipality. African Journal of Food, Agriculture, Nutrition and Development. 2014;14(5):2057-71.

20. Do LM, Tran TK, Eriksson B, Petzold M, Nguyen CT, Ascher H. Preschool overweight and obesity in urban and rural Vietnam: differences in prevalence and associated factors. Global health action. 2015;8(1):28615.

21. Spurrier NJ, Magarey AA, Golley R, Curnow F, Sawyer MG Relationships between the home environment and physical activity and dietary patterns of preschool children: a crosssectional study. International Journal of Behavioral Nutrition and Physical Activity. 2008;5(1):31.

22. Elkum N, Al-Arouj M, Sharifi M, Shaltout A, Bennakhi A Prevalence of childhood obesity in the state of Kuwait. Pediatric obesity. 2016;11(6):e30-e4

23. Discigil G, Tekin N, Soylemez A. Obesity in Turkish children and adolescents: prevalence and non-nutritional correlates in an urban sample. Child: care, health and development. 2009;35(2):153-8

24. Hassan MK, Musa WA. Overweight and obesity among preschoo children in Basrah. The Medical Journal of Basrah University. 2010;28(1):1-8.

25. Goyal RK, Shah VN, Saboo BD, Phatak SR, Shah NN, Gohel $\mathrm{MC}$, et al. Prevalence of overweight and obesity in Indian adolescent school going children: its relationship with socioeconomic status and associated lifestyle factors. The Journal of the Association of Physicians of India. 2010;58:151-8.

26. Birch L, Ventura A. Preventing childhood obesity: what works? International journal of obesity. 2009;33(S1):S74

27. Warren R, Wicks JL, Wicks RH, Fosu I, Chung D. Food and Beverage Advertising to Children on US. Television: Did National Food Advertisers Respond? Journalism \& Mass Communication Quarterly. 2007;84(4):795-810.

28. Harris JL, Bargh JA, Brownell KD. Priming effects of television food advertising on eating behavior. Health psychology. 2009;28(4):404.

http://edergi.cbu.edu.tr/ojs/index.php/cbusbed isimli yazarın CBU-SBED başlıklı eseri bu Creative Commons Alınt1-Gayriticari4.0 Uluslararası Lisansı ile lisanslanmıștır. 